\title{
Evaluating the bio-hydrological impact of a cloud forest in Central America using a semi-distributed water balance model
}

\author{
Luis A. Caballero ${ }^{1,2}$, Zachary M. Easton ${ }^{3}$, Brian K. Richards ${ }^{1}$ and Tammo S. Steenhuis ${ }^{1 *}$ \\ ${ }^{1}$ Department of Biological and Environmental Engineering, 206 Riley Robb Hall, Cornell University, Ithaca, NY, 14853, USA. \\ ${ }^{2}$ Department of Environment and Development Studies, Zamorano University, Zamorano, Honduras. \\ ${ }^{3}$ Department of Biological Systems Engineering, Eastern Shore Agricultural Research and Extension Center, Virginia Tech, 33446, \\ Research Driver Painter, VA, 23420, USA. \\ *Corresponding author. Tel.: +1 607255 2489. E-mail: tss1@cornell.edu
}

\begin{abstract}
Water scarcity poses a major threat to food security and human health in Central America and is increasingly recognized as a pressing regional issues caused primarily by deforestation and population pressure. Tools that can reliably simulate the major components of the water balance with the limited data available and needed to drive management decision and protect water supplies in this region. Four adjacent forested headwater catchments in La Tigra National Park, Honduras, ranging in size from 70 to 635 ha were instrumented and discharge measured over a one year period. A semi-distributed water balance model was developed to characterize the bio-hydrology of the four catchments, one of which is primarily cloud forest cover. The water balance model simulated daily stream discharges well, with Nash Sutcliffe model efficiency (E) values ranging from 0.67 to 0.90 . Analysis of calibrated model parameters showed that despite all watersheds having similar geologic substrata, the bio-hydrological response the cloud forest indicated less plantavailable water in the root zone and greater groundwater recharge than the non cloud forest cover catchments. This resulted in watershed discharge on a per area basis four times greater from the cloud forest than the other watersheds despite only relatively minor differences in annual rainfall. These results highlight the importance of biological factors (cloud forests in this case) for sustained provision of clean, potable water, and the need to protect the cloud forest areas from destruction, particularly in the populated areas of Central America.
\end{abstract}

Keywords: Central America; Rainfall-runoff; Thornthwaite-mather; Water balance model; Cloud forest; Monsoonal climate.

\section{INTRODUCTION}

Throughout the world water demand has increased in response to population growth, agricultural use, and industrial demand (PHO, 2000), while in countries with a monsoonal climate, water supplies in the dry phase are shrinking due to deforestation (San Martin, 2001; Barlow and Clarke, 2002; Bonell and Bruijnzeel, 2004; Bruijnzeel, 2004). This coupled with increasing pollution levels from inadequate waste treatment and increased use of agrichemicals (PHO, 2000) has led to potable water shortages. As a result, policymakers in these countries are under increasing pressure to enact natural resource management policies for preservation of water source areas to ensure clean and adequate potable water. For instance, in Honduras many of the water supply systems have cloud forests as the water source areas (Mulligan and Burke, 2005). Cloud forests are defined as having abundant presence of epiphytes and are characterized by persistent, frequent or seasonal cloud cover at the vegetation level (Hamilton et al., (1993). Although new laws are being implemented it is widely recognized that the lack of quantitative science-based knowledge may hinder effective application.

Developing relevant natural resources policies to effectively manage water resources is a complex process. Models could provide insight, but unfortunately, most available hydrologic models such as the Soil and Water Assessment Tool model (Arnold et al., 1996; Easton et al. 2010), MIKE-SHE, Hydrologic Engineering Center (HEC) model (Jenícek, 2009) and the FRIER rainfall-runoff model (Horvat et al., 2009), need detailed landscape and rainfall information that is not available in Latin America. Moreover, the rainfall-runoff relationships in these models are based on temperate climate for which these models were validated (Bruijnzeel, 2004; Araujo et al., 2008; Steenhuis et al., 2009) and application of these models to a monsoonal climate with a unique hydro biological characteristics remains problematic (Kovacs, 1984; Falkenmark and Chapman, 1993; Musiake, 2003; Peel et al., 2004 and Sivapalan, 2003).

Landscapes such as cloud forests play a key role in providing water to the lower and drier portions of watersheds in Latin America (Buytaert et al., 2005). Very few studies on the biohydrologic impact of cloud forests have been carried out (Cavelier et al., 1997 in Panama; Bruijnzeel et al., 2006 and Schellekens, 2006 in Costa Rica). Buytaert et al., (2006) compared the water balances of two small catchments in the páramo of Ecuador, one similar to cloud forests and one a disturbed agricultural system. and found that the natural vegetation maximized water retention in the soil by minimizing the plantavailable water for evaporation. This made more water available for base and interflow in the cloud forest than in the disturbed system.

One model that has been specifically developed for cloud forests is the CQflow model (Schellekens, 2006). The CQflow model is fully distributed and simulates (among other factors) fog interception. Recently, Topmodel has been successfully applied in the páramo in the Ecuadorian Andes (Buytaert and Beven, 2011) and the Jizera Mountains in Czech Republic (Pavelkova et al., 2012). Another potential model that has been used in a wide variety of physiographic locations is the Thornthwaite Mather procedure (Thornthwaite, 1948; Thornthwaite and Mather, 1955; Steenhuis and van der Molen, 1986) and has been recently adapted for monsoon climates by separating the watershed into infiltration/recharge zones and runoff zones via saturation excess mechanisms. (Peranginangin 
et al., 2004; Steenhuis et al., 2009; Bayabil et al., 2010; Tesemma et al., 2010). The model is similar to the method developed at the same time by Budagovskiy (1964; cited by Shumova, 2009) in the Soviet Union.

Our general objective is to increase knowledge on the interaction of hydrology and biological factors in cloud forests in Latin America by presenting a comprehensive analysis of physically based watershed model parameters using data from a recent study that measured rainfall and discharge from a cloud forest and three surrounding forested watersheds in the La Tigra National Park in Honduras (Caballero et al., 2012). Differences in model parameters between cloud forests and the other, non-cloud forest watersheds are used to infer the effect of cloud forests on bio-hydrological factors.

\section{MATERIALS AND METHODS Site description}

La Tigra Experimental Catchment is located $\left(87^{\circ} 5^{\prime} \mathrm{W}\right.$ latitude and $14^{\circ} 10^{\prime} \mathrm{N}$ longitude) within La Tigra National Park, $25 \mathrm{~km}$ north east of Tegucigalpa, central Honduras in the headwaters of the Choluteca River Basin, which drains into the Pacific Ocean (Fig. 1). La Tigra Park supplies 30\% and 50\% of drinking water for Tegucigalpa (Campanella et al., 1982). During the dry months (March, April and May) other sources of drinking water (the Guacerique and Concepcion reservoirs) decrease greatly due to lack of baseflow and La Tigra National Park becomes the main supply for Tegucigalpa (Stadtmüller, 1987).

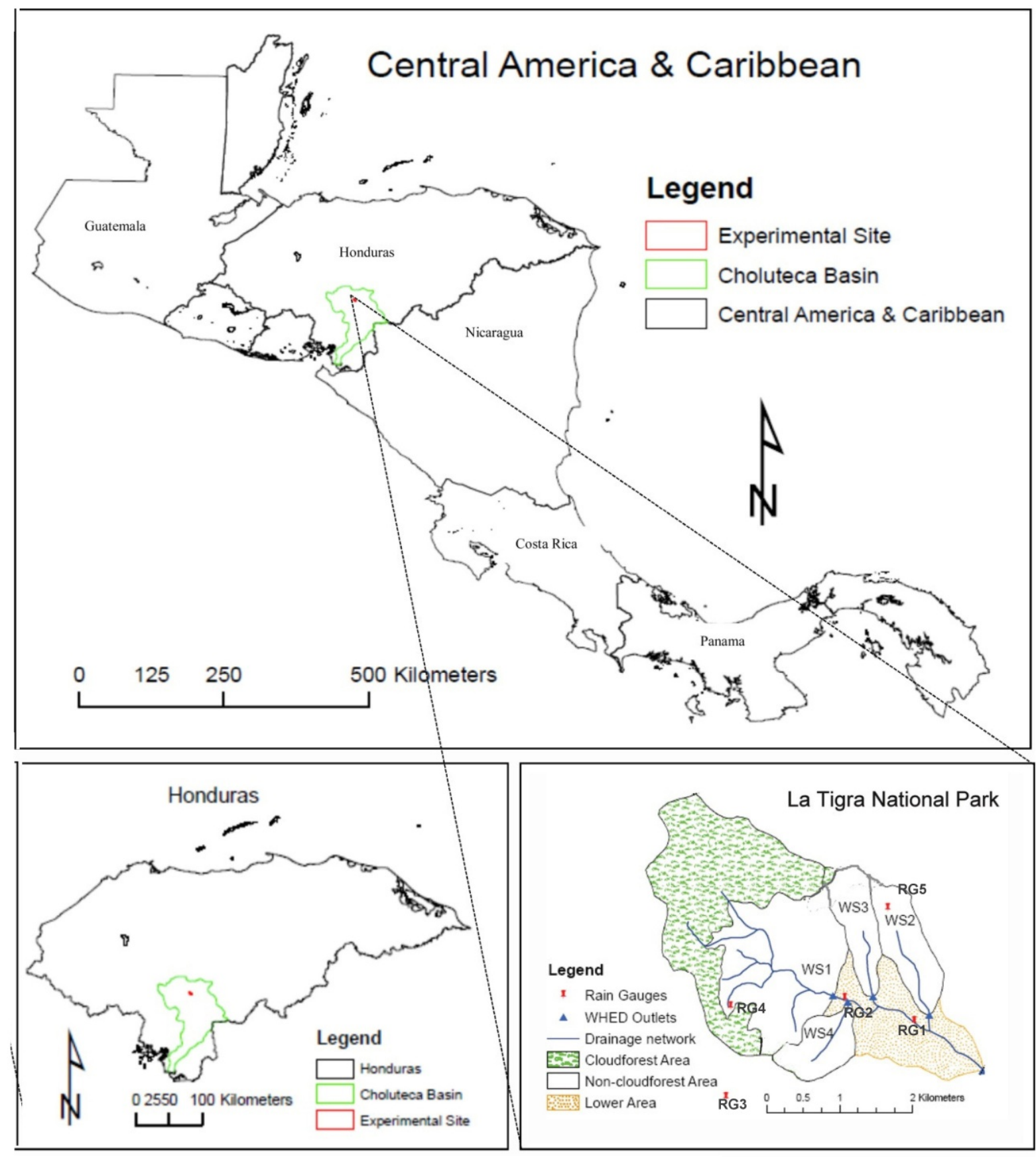

Fig. 1. Study site, La Tigra Experimental Catchment, Honduras. 
The experimental site is composed of four neighboring headwater catchments (WS1, WS2, WS3 and WS4, Fig. 1) together comprising an area of 880 ha. The research area is characterized by steep slopes ranging from 20 to $30 \%$. The mean slopes of the stream channels for the catchments range from 14 to $21 \%$. The general characteristics of each watershed are summarized in Table 1. Watersheds WS3 has withdrawals that serve as the water supply for the municipality of Valle de Angeles.

The study area has been protected since the 1940's, first as forest reserve, and more recently as national park. Land cover is predominantly evergreen Pinus oocarpa at lower elevations up to $1500 \mathrm{~m}$. Above $1800 \mathrm{~m}$ a mixture of Pinus maximinow and various broadleaf plants (mainly Quercus species) are found. Between 1500 and 1800 there is a transition zone between the two vegetation covers. Cloud forest land cover was $58 \%$ for WS1, $0 \%$ for WS2, less than $4 \%$ for WS3 and $0 \%$ for WS 4 (Table 1). A 2010 land use survey indicates that forest cover is predominant in all sites, except in WS4 where $16 \%$ is under agricultural cultivation (Table 1). The cloud forest is exposed to fog and lower temperatures, approximately $5-10^{\circ} \mathrm{C}$ (Bruijnzeel et al., 2006). Unpublished data from the Uyuca Mountains 14 $\mathrm{km}$ southeast indicate that temperatures drop approximately $6^{\circ} \mathrm{C}$ per $1000 \mathrm{~m}$ of elevation gain (Agudelo, 2010: personal communication).

The climate is characteristic of monsoonal regions with very distinct dry and wet phases. The wet phase begins at the end of May or early June when the Intertropical Convergence Zone (ITCZ) becomes active, bringing warm moist clouds from the eastern Pacific to Central America and the Caribbean (Hastenrath, 2002). The slopes of the watershed face predominantly southeast (Fig. 1). Since the trade winds are from the northwest, the watershed lies in the rain shadow. Annual precipitation averaged over the watershed is $1150 \mathrm{~mm}$, with $90 \%$ of the rainfall falling from the end of May through October (Fig. S1 Supplementary material). These amounts are approximately half of that recorded in 1987 by Stadtmüller and Agudelo (1990) at the ridge of the mountain around $1850 \mathrm{~m}$ in the Cerro Uyuca Biological Reserve $30 \mathrm{~km}$ to the south east of the La Tigra watershed.

Table 1. Characteristics of the four study catchments and their rivers in La Tigra National Park, Honduras, Central America.

\begin{tabular}{|c|c|c|c|c|}
\hline & \multicolumn{4}{|c|}{ CATCHMENT } \\
\hline & WS1 & WS2 & WS3 & WS4 \\
\hline Catchment area (ha) & 635 & 93 & 82 & 70 \\
\hline Cloud forest area $\%$ & 58 & 0 & 4 & 0 \\
\hline Other forested \% & 41 & 100 & 96 & 84 \\
\hline Deforested \% & 1 & 0 & 0 & 16 \\
\hline Weir elevation at outlet (m) & 1505 & 1374 & 1431 & 1486 \\
\hline Elevation range $(\mathrm{m})$ & $1505-2270$ & $1374-1850$ & $1431-2000$ & $1486-1960$ \\
\hline Mean elevation (m) & 1905 & 1625 & 1730 & 1715 \\
\hline Mean slope $(\%)$ & 22 & 20 & 27 & 30 \\
\hline Main stream channel length (m) & 6600 & 1508 & 1105 & 994 \\
\hline Main stream channel slope $(\%)$ & 18 & 14 & 18 & 21 \\
\hline Drainage density $\left(\mathrm{km} / \mathrm{km}^{2}\right)$ & 1.00 & 1.62 & 1.35 & 1.42 \\
\hline Mean annual temperature $\left({ }^{\circ} \mathrm{C}\right)$ & $16-20$ & $16-20$ & $16-20$ & $16-20$ \\
\hline Mean annual precipitation (mm) & 1085 & 1085 & 1085 & 1085 \\
\hline Mean annual discharge (mm) & 520 & - & - & - \\
\hline Geology (bedrock formation) & Volcanic & Volcanic & Volcanic & Volcanic \\
\hline Period of measurements & $\begin{array}{l}\text { Apr. } 2008- \\
\text { Dec. } 2009\end{array}$ & $\begin{array}{l}\text { Apr. 2009- } \\
\text { Dec. } 2009\end{array}$ & $\begin{array}{c}\text { Wet season } 2009 \\
\text { Intermittent }\end{array}$ & $\begin{array}{l}\text { Wet season } \\
2009\end{array}$ \\
\hline Type of stream & Perennial & Perennial & & Intermittent \\
\hline
\end{tabular}

Soils of the research catchments are Andisols of volcanic origin. A detailed soil map is not available for the study catchments, but based on geologic mapping, soils are underlain by silicate strata of medium coarse fragments of igneous, volcanic and calcareous rocks (IGN, 1956). The lower part of the La Tigra watershed has soils depths ranging from 0.3 to 0.9 meters, organic matter contents from 5 to $15 \%$ (Lavaire and Fiallos, 2010). Soils have abundant large pores, roots, and rock fragments which contribute to high permeabilities. Saturated hydraulic conductivities on disturbed soil samples ranged from 1.6 to $7 \mathrm{~cm} \mathrm{hr}^{-1}$ (Lavaire and Fiallos, 2010). A soil survey in a similar cloud forest ecosystem in the Capiro-Zapotillo microcatchments reported mean organic matter contents in excess of $7 \%$, with values reaching $14 \%$ in the uppermost cloud forest areas. Bulk densities ranged from 0.4 to $1.0 \mathrm{gr} \mathrm{cm}^{-3}$ (Martinez, 2008). Martinez (2008) found soil depths ranging from 0.6 to $1.2 \mathrm{~m}$ and sometimes even greater in the upper part of the catchments.

\section{Hydrologic data sets}

Stream discharge was measured at each catchment outlet through a weir (Fig. S2 Supplementary material). Water height were recorded on 10-minute intervals, and converted to volume using standardized rating curves (ISO, 1980; Caballero et al., 2012).

Precipitation was measured by a network of five digital rain gages located along the elevation gradient $(1350-1850 \mathrm{~m})$ to have a representative measurement of the average precipitation over the research sites. The potential evaporation was obtained from a nearby $(20 \mathrm{~km})$ digital weather station located on the grounds of the Pan-American School of Agriculture (Zamorano University).

\section{Rainfall-runoff model}

We present only the conceptual Semi-Distributed Water Balance Model (SWB model), with the complete derivation 
from Tesemma et al. (2010) (available in preprint form at http://soilandwater.bee.cornell.edu/publications/zelalembluenile-2012.pdf). The model as shown by Walter et al. (2002) is mathematically similar to Topmodel with the exponential decreasing conductivity as used by Buytaert and Beven (2011). However, in Topmodel the entire watershed is underlain by a regional groundwater table that periodically intersects the soils surface generating runoff while in the SWB model shallow perched water tables over a slowly permeable layer govern the formation of saturated runoff producing areas. In the SWB model the landscape is divided into two regions: well-drained hillslopes, and the flatter near stream areas that become saturated during the wet season due to upslope flow contributions. The hillslopes are further subdivided into two groups: degraded areas that have the hardpan exposed at the soil surface, and highly permeable soils above a restrictive layer at some depth. In the degraded areas (or rock outcrops) that have restricted infiltration, only a small amount of water can be stored before saturation excess surface runoff occurs. In contrast, on the highly permeable portion of the hillslopes, most of the water is transported as rapid subsurface flow (i.e., interflow over a restrictive layer) or as base flow that percolates from the soil profile to deeper subsoil and rock layers (Šanda and Císlerová, 2009, Steenhuis et al., 2009, Bayabil et al., 2010). The flatter areas that drain the surrounding hillslopes become runoff source areas when part of the profile is at or near saturation. Three separate water balances are calculated for each region. The water balance for the each of the three areas can be written as:

$$
S_{S}(t)=S_{s}(t-\Delta t)+\left[P-E_{a}-R-P_{e r c}\right] \Delta t,
$$

where $S_{s}(t)$ is volume of plant available water in the soil profile above the restrictive layer per unit area (L), at time $t(T), S_{s}(t-$ $\Delta t)$ is the previous time step water storage $(\mathrm{L}), P$ is rainfall $(\mathrm{L}$ $\left.\mathrm{T}^{-1}\right), E_{a}$ is actual evapotranspiration $\left(\mathrm{L} \mathrm{T}^{-1}\right), R$ is saturation excess runoff $\left(\mathrm{L} \mathrm{T}^{-1}\right), P_{\text {erc }}$ is percolation to the subsoil $\left(\mathrm{L} \mathrm{T}^{-1}\right)$ and $\Delta t$ is the time step ( 1 day in our case). Percolation from the infiltration zone occurs when the moisture inputs exceed field capacity. Surface runoff is produced when the soil is saturated and is equal to the amount of rainfall minus the water needed to saturate the soil profile. The actual evaporation from the soil, $E_{a}$ is calculated with the Thornthwaite-Mather procedure (Thornthwaite, 1948; Thornthwaite and Mather, 1955; Steenhuis and van der Molen, 1986). The method assume that evaporation decreases linearly with soil moisture content between field capacity (at which point $E_{a}$ equals potential evaporation) and the wilting point (at which $E_{a}$ is zero). Once precipitation has infiltrated below the root zone there are two reservoirs, one for baseflow and one for interflow. The baseflow reservoir is associated with the groundwater in the near stream area and is simulated as linear reservoir with exponentially decreasing discharge. The interflow reservoir simulates water flowing down the slope over the restrictive layer and is a zero order reservoir (e.g., the discharge decreases linearly with reservoir volume).

\section{Evaluation of model performance}

To evaluate how well the predicted discharge matched observed values, we used the Nash-Sutcliffe model efficiency coefficient (E) or goodness-of-fit index (Nash-Sutcliffe, 1970), which is widely used to evaluate the predictive capacity of hydrologic models. In addition, the performance of the model during calibration was evaluated using the normalized root mean squared error (RMSE) and regression coefficient, $\mathrm{R}^{2}$.

\section{RESULTS}

The hydrographs of the four watersheds in the La Tigra National Park were distinctly different (solid black lines in Fig. 2). In WS1 (cloud forest, Fig. 2a) the hydrograph is characterized by an initially steep receding limb (October-December) becoming more and more shallow until the next rainfall season begins, usually in late May. Although smallest WS2 has streamflow throughout the year, the discharge is less than in WS1 and thus the portion of rain converted to streamflow is smaller (Fig. 2b). In the two watersheds WS3 (Fig. 2c) and WS4 (Fig. 2d), there was only discharge in the wet, monsoon phase. In general, WS1 and WS2 have similar runoff responses during the wet season (Figs 2a and 2b). In WS3 and WS4, discharge drastically declines during the short rainless period between the wet seasons (Figs 2c and 2d).

In the following sections, we use the SWB model parameters to investigate hydrological processes and how these parameters can explain differences in hydrological behavior among the four watersheds. The SWB model is a mathematical relationship between rainfall and evaporation (as input parameters) and the watershed discharge (as an output). Because the hydrograph is the output signal that integrates all processes that occur in the watershed, it is unlikely parameters resulting in a poor fit represent the physical processes occurring in the watershed. This approach, however, does not give insight into selecting from among potential mechanisms whether they all fit the model with equal precision. Hence, when a good fit is obtained between observed and predicted outflow, we can assume that the hydrologic processes in the underlying model structure are valid. For example if the total discharge does not vary as a function of rainfall intensity, infiltration excess is likely not occurring in the watershed.

\section{Model fitting}

The semi-distributed SWB model applied here used the precipitation and potential evaporation as climatic input data to estimate the water balance. For precipitation $(P)$, daily arithmetic averages obtained from either three or four digital rain gages were used and thus daily precipitation model inputs were the same for all catchments (Fig. S3 in Supplementary material). Potential evaporation $(P E)$ data from a nearby $(20 \mathrm{~km})$ weather station was used, which ranged from 1.3 to $5.6 \mathrm{~mm} \mathrm{~d}^{-1}$, with an average of $3.6 \mathrm{~mm} \mathrm{~d}^{-1}$ over the measurement period a value quite similar to the $3.5 \mathrm{~mm} \mathrm{~d}^{-1}$ used in monsoonal climate of Ethiopia (Collick, et al., 2009) and in the Caribbean (2.1-3.7 $\mathrm{mm} \mathrm{d}^{-1}$, Charlier et al., 2008). Other parameters needed to simulate the discharge included soil water storage capacity for the hillslopes and runoff contributing areas. The saturated areas were designated as those areas at the foot of the hills where saturation excess runoff is generated as well as areas of exposed bedrock (see picture S4 in Supplementary material). Saturation excess runoff in these highly conductive soils does not necessarily mean that the water table is at the surface. Only part of the soil profile needs be saturated for interflow to occur (Lyon et al., 2006). The hillslopes act as sources of the recharge to the aquifer and contribute flow to the saturated runoff generating areas via interflow from upslope areas.

We initially planned to calibrate the model for WS1 and then validated the model for the other watersheds, but once the data were analyzed it became clear that although we could close the 
a)

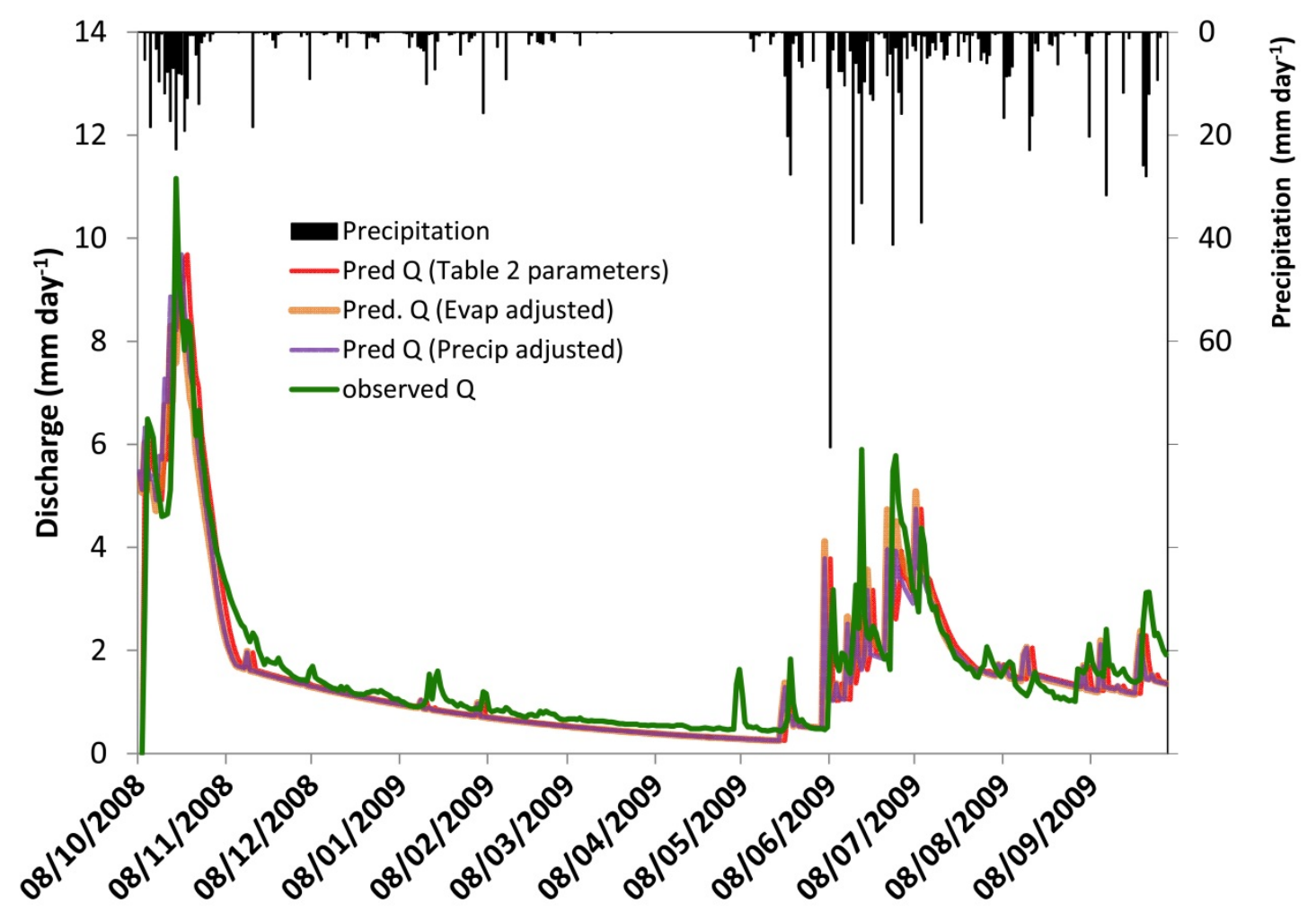

b)

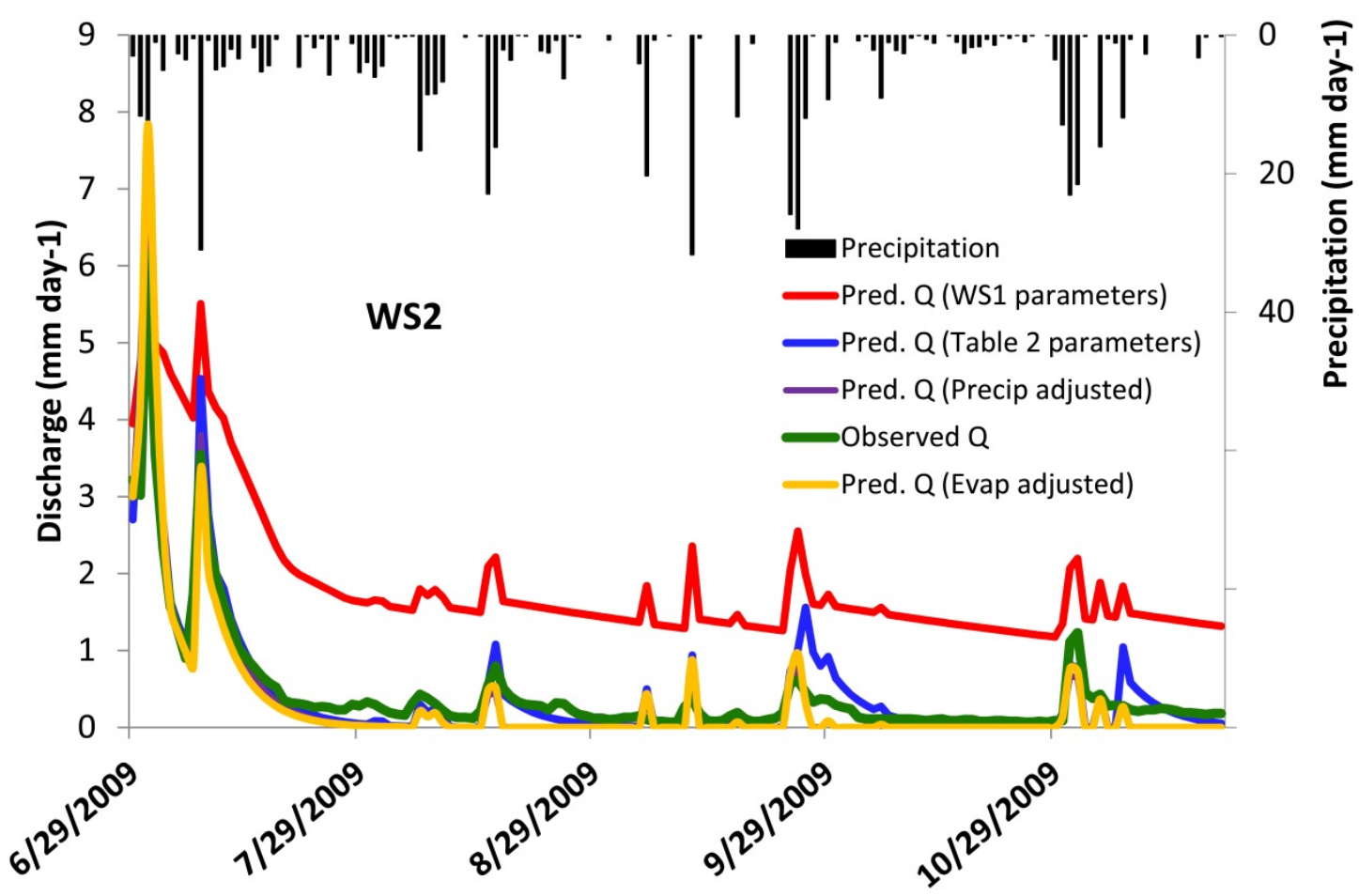


c)

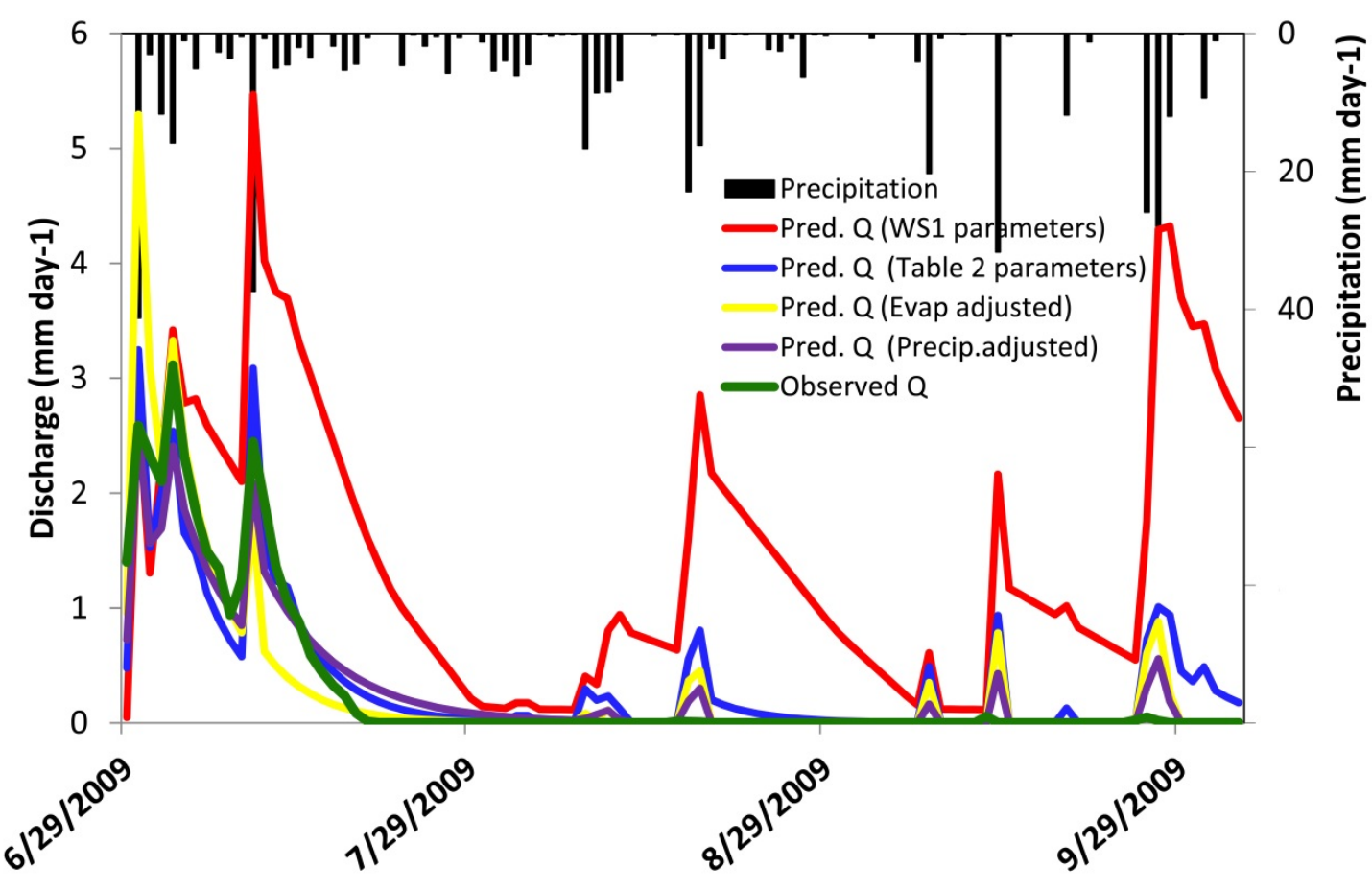

d)

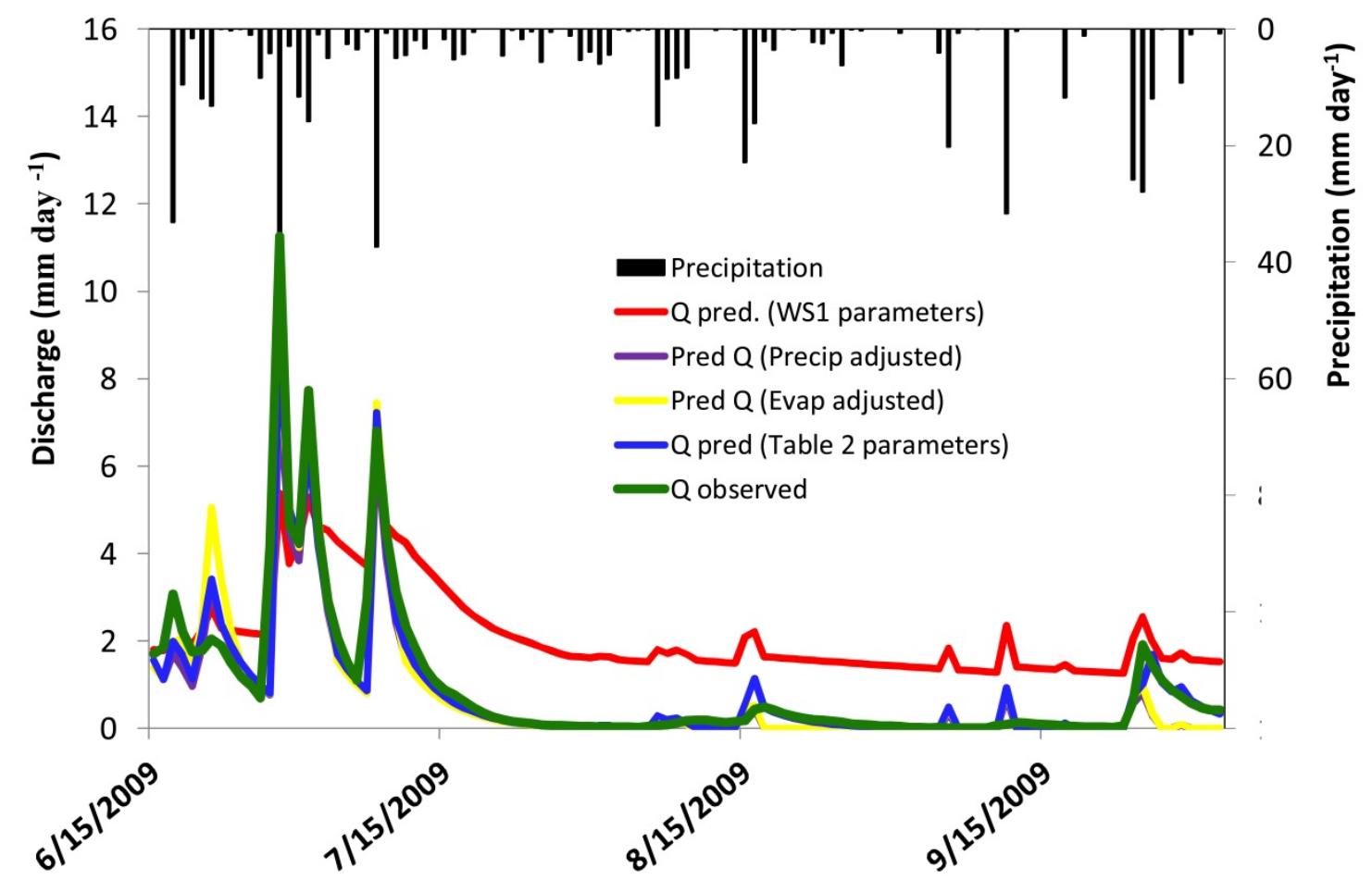

Fig. 2. Comparison of observed and predicted daily total stream discharges for the four watersheds for the input parameters listed Table 2 and 3: a) Watershed WS1, b) Watershed WS2; c) Watershed WS3 and d) Watershed WS4. The explanation of the legend is given in Table 3. (Colour version of the figure can be found in the web version of this article.) 
water balance for WS1, this was not possible for the other watersheds. For this reason, we first fitted the observed and predicted values for WS1 and then changed the fewest number of parameters to fit the other three watersheds using a simplified equifinality approach by varying those parameters within physically-justifiable ranges. We first adjusted the area that contributed runoff in order to fit the observed versus predicted values. Once we had the mass balance correctly fitted, the available water content of the soil was fitted, and subsequently a sensitivity analysis was performed in which we varied the precipitation and potential evaporation (Table 3 ).

Table 2. Model input parameter values for surface flow, baseflow and interflow for the four catchments in the La Tigra National Park in Honduras.

\begin{tabular}{lrrrr}
\hline \multirow{2}{*}{ Parameter } & \multicolumn{4}{c}{ Watershed } \\
\cline { 2 - 5 } & WS1 & WS2 & WS3 & WS4 \\
\hline Overland flow area & 0.04 & 0.04 & 0.04 & 0.04 \\
Permeable hill slope area (fraction) & 0.96 & 0.80 & 0.30 & 0.70 \\
$t^{*}$ for interflow zero order reservoir (days) & 20 & 3 & 3 & 3 \\
$t_{1 / 2}$ half-life aquifer (days) & 70 & 2.3 & 2.3 & 2.3 \\
Maximum depth ground water reservoir (mm) & 200 & 15 & 15 & 15 \\
$S_{\max }$ overland flow area (mm) & 5 & 5 & 5 & 5 \\
$S_{\max }$ hill slope zone (mm) & 20 & 200 & 200 & 200 \\
\hline
\end{tabular}

Table 3. Comparison of observed versus model predicted daily discharge for the four watershed WS1, WS2, WS3 and WS4. The Mean, Standard deviation (St Dev), root mean square error (RMSE), Nash Sutcliff Efficiency (Nash Sut) and the intercept (interc), slope and $\mathrm{R}^{2}$ of the linear regression are given for various simulations. For "Table 2 parameters" the values listed in Table 2 for the particle watershed are used. We also used the input values for Watershed WS1 for simulating the discharge of Watersheds WS2, WS3 and WS4 (WS1 parameters) and the WS2 parameters for simulating WS1 (WS2 parameters); Best fits were also obtained by setting the total contributing area to 1 while keeping the other model parameters in Table 2 for the particular watershed in Table 2 the same by multiplying the precipitation by a constant factor listed under "Ratio" (Precipitation adjusted) or by multiplying the potential evaporation by a constant factor (Evaporation adjusted). The value in "Ratio" was the best fit value.

\begin{tabular}{|c|c|c|c|c|c|c|c|c|c|}
\hline \multirow{2}{*}{$\begin{array}{l}\text { Water- } \\
\text { shed }\end{array}$} & \multirow[t]{2}{*}{ Description } & \multirow[t]{2}{*}{ Ratio } & \multirow{2}{*}{$\begin{array}{c}\text { Mean } \\
\text { (mm/day) }\end{array}$} & \multirow{2}{*}{$\begin{array}{c}\text { St dev } \\
\text { (mm/day) }\end{array}$} & \multirow{2}{*}{$\begin{array}{c}\text { RMSE } \\
\left(\mathrm{mm} \mathrm{d}^{-1}\right)\end{array}$} & \multirow{2}{*}{$\begin{array}{l}\text { Nash } \\
\text { Sutc }\end{array}$} & \multicolumn{3}{|c|}{ Linear regression } \\
\hline & & & & & & & interc & slope & $\mathrm{R}^{2}$ \\
\hline \multirow{5}{*}{ WS1 } & Observed & & 1.74 & 1.60 & & & & & \\
\hline & Table 2 parameters & & 1.70 & 1.69 & 0.62 & 0.85 & 0.07 & 0.96 & 0.89 \\
\hline & WS2 parameters & & 0.54 & 1.59 & 1.64 & -0.05 & 0.15 & 0.97 & 0.89 \\
\hline & Precipitation adjusted & 0.90 & 1.58 & 1.64 & 0.54 & 0.89 & 0.27 & 0.93 & 0.90 \\
\hline & Evaporation adjusted & 1.30 & 1.57 & 1.57 & 0.51 & 0.90 & 0.20 & 0.97 & 0.90 \\
\hline \multirow{5}{*}{ WS2 } & Observed & & 0.47 & 0.80 & & & & & \\
\hline & WS1 parameters & & 1.88 & 0.96 & 1.48 & -2.43 & 1.38 & 1.07 & 0.80 \\
\hline & Table 2 parameters & & 0.47 & 0.98 & 0.30 & 0.86 & -0.08 & 1.18 & 0.93 \\
\hline & Precipitation adjusted & 0.85 & 0.35 & 0.99 & 0.29 & 0.87 & 0.21 & 1.20 & 0.95 \\
\hline & Evaporation adjusted & 1.40 & 0.33 & 0.97 & 0.31 & 0.85 & -0.22 & 1.18 & 0.94 \\
\hline \multirow{5}{*}{ WS3 } & Observed & & 0.31 & 0.70 & & & & & \\
\hline & WS1 parameters & & 1.44 & 0.72 & 1.45 & -4.27 & 1.17 & 0.90 & 0.26 \\
\hline & Table 2 parameters & & 0.38 & 0.64 & 0.32 & 0.78 & 0.13 & 0.82 & 0.80 \\
\hline & Precipitation adjusted & 0.60 & 0.31 & 0.70 & 0.21 & 0.91 & 0.07 & 0.78 & 0.94 \\
\hline & Evaporation adjusted & 2.10 & 0.33 & 0.82 & 0.38 & 0.67 & 0.02 & 1.0 & 0.78 \\
\hline \multirow{5}{*}{ WS4 } & Observed & & 0.98 & 1.72 & & & & & \\
\hline & WS1 parameters & & 2.16 & 1.06 & 1.57 & 0.16 & 1.67 & 0.51 & 0.67 \\
\hline & Table 2 parameters & & 0.87 & 1.51 & 0.54 & 0.90 & 0.05 & 0.84 & 0.91 \\
\hline & Precipitation adjusted & 0.83 & 0.71 & 1.40 & 0.66 & 0.85 & -0.04 & 0.77 & 0.89 \\
\hline & Evaporation adjusted & 1.30 & 0.81 & 1.64 & 0.65 & 0.85 & 0.05 & 0.88 & 0.86 \\
\hline
\end{tabular}

\section{Calibration for WS1}

The predicted and observed streamflow for the WS1 watershed (cloud forest) for the period October 2008 through October 2009 is shown in Fig. 2a) as the red line. Average observed streamflow was $1.7 \mathrm{~mm} \mathrm{~d}^{-1}$ and model-predicted discharge was $1.6 \mathrm{~mm} \mathrm{~d}^{-1}$ (Table 3 ) this best fit was obtained with only $4 \%$ of the watershed area contributing surface runoff, while the remaining $96 \%$ the watershed infiltrated precipitation and contributed subsurface flow (Table 2). Surface runoff was produced when the rainfall exceeded the calibrated maximum available rootzone water content of $5 \mathrm{~mm}$ (e.g. $S_{\max }=5 \mathrm{~mm}$, Table 2) in the soil, and thus any rain with $5 \mathrm{~mm}$ or more pro- duced at least some runoff. The runoff areas are saturated areas caused by interflow from upslope or exposed bedrock (Harpold et al., 2010). Thus $96 \%$ of the watershed had soils with high infiltration rates in which all rainfall infiltrated. Subsurface flow consists of slow (baseflow) and fast (interflow) components. Baseflow was simulated as a linear reservoir with a halflife of 70 days. In the model, the groundwater reservoir fills first, and when the storage exceeds the equivalent of $200 \mathrm{~mm}$ over the whole watershed the zero order interflow reservoir fills and drains in 20 days (by calibration, Table 2). The time that interflow stops is clearly visible in Fig. 2a) where on November $10^{\text {th }} 2009$, the rapid decline in discharge (i.e., interflow) stops, and the slope of the receding limb becomes much less steep 
(i.e., baseflow). The Nash-Sutcliffe model efficiency is 0.85 , which is quite good for daily discharge predictions (Table 3 ). The $\mathrm{R}^{2}$ was 0.89 and the slope close to 1 (Table 3, Fig. 3a)). The model predicted that an average of $1.4 \mathrm{~mm} \mathrm{~d}^{-1}$ of rainfall exited the watershed as subsurface flow, which was nearly equal to the $1.6 \mathrm{~mm} \mathrm{~d}^{-1}$ obtained from baseflow separation technique (Caballero et al., 2012).

a)

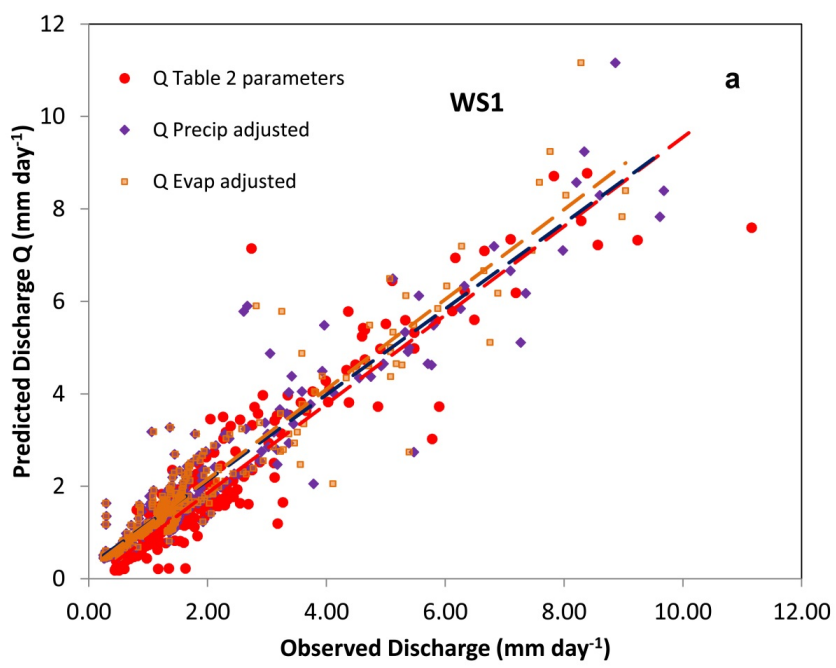

b)

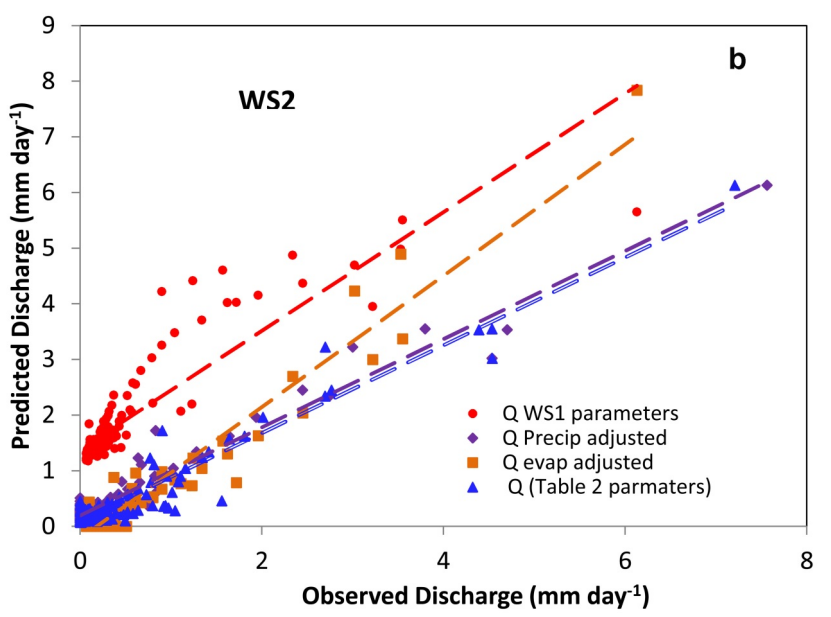

c)

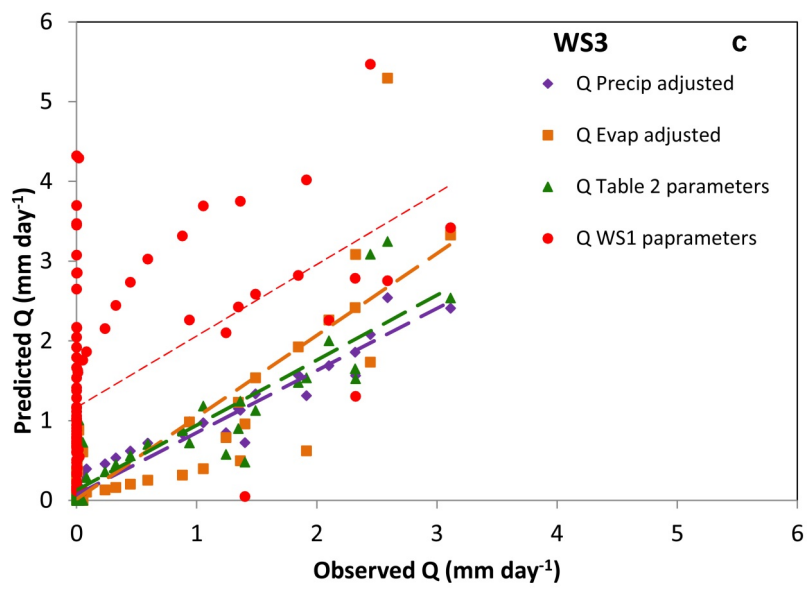

d)

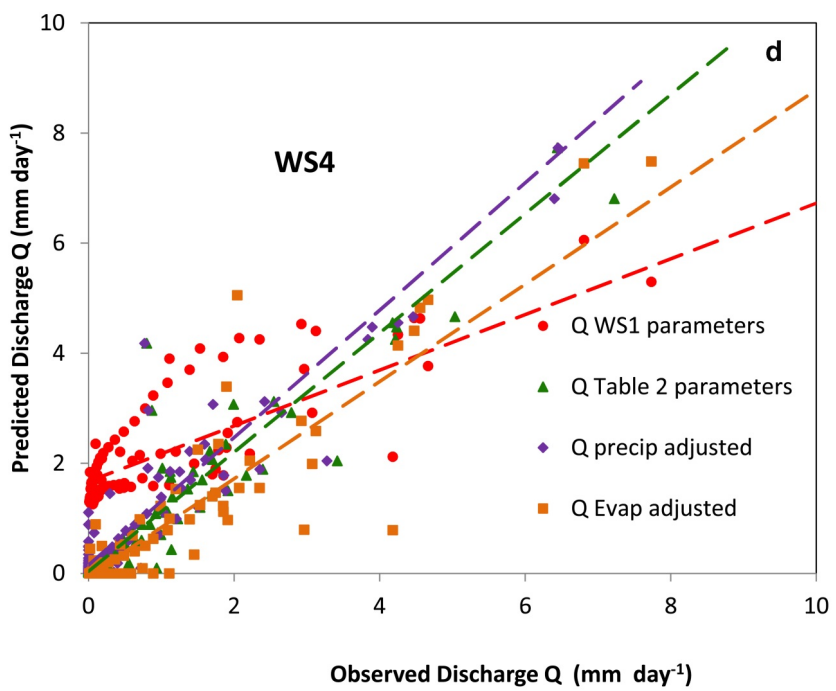

Fig. 3. Comparison of observed and predicted daily total streamflow discharges for the four watersheds for various sets of input parameters listed Table 2 and 3. a) Watershed WS1, b) Watershed WS2; c) Watershed WS3 and d) Watershed WS4. The dashed lines are the linear regression lines and have the same color as the symbols. For explanation of both the legend and the value of the linear regression coefficients see Table 3 . (Colour version of the figure can be found in the web version of this article.)

\section{Calibration for WS2, WS3 and WS4}

For the three smaller watersheds, which had little or no cloud forest cover, we initially transferred the calibrated parameter set for WS1 (Table 2) but the fit was poor with Nash Sutcliffe values that were either close to zero or negative (Table 3; redline in Fig. 2b, c and d) and we tried to fit the hydrographs of each watershed by changing one parameter at a time until a good fit was obtained. For every trial, we used the coefficient of determination $\left(\mathrm{R}^{2}\right)$ and a slope close to 1 as a measure of good fit. The final model performance was also evaluated using the Nash Sutcliffe efficiency $\left(\mathrm{E}^{*}\right)$ and the root mean square error (RMSE) (Table 3).

Model calibration was performance as follows: We first ensured that the water balances (observed and modeled) in each of the watersheds were as close as possible, by adjusting contributing areas of the hillslopes that provided water at the gage as runoff on the day of the rainfall, and sometime later for interflow and baseflow (Table 2). The water balance closed when the hillslope areas were fixed at $80 \%$ of the total area for WS2, $70 \%$ for WS4 and $30 \%$ for WS3 (Table 2). The remaining rainfall that not evaporated becomes interflow or baseflow down from the gage. The fit between daily observed and predicted values was still poor and required adjusting the other model parameters (i.e., maximum depth of ground water reservoir and $S_{\max }$ ). This was done first for WS2. Since the watersheds did not differ greatly except for the cloud forest cover, we kept the total of ground water and root zone storage for the hillslope area constant at approximately $220 \mathrm{~mm}$ (Table 2). In order to obtain a better fit we increased the maximum available rootzone water content, $S_{\max }$, to $200 \mathrm{~mm}$ and reduced the maximum ground water storage to $15 \mathrm{~mm}$, (Table 2) yielding a total storage of $215 \mathrm{~mm}$ for WS2 compared with $220 \mathrm{~mm}$ for SW1. Finally, to obtain good fits for the recession curves we adjusted decay constant for subsurface flows. Our experience in other monsoonal climates (Collick et al., 2009; Steenhuis et al., 2009) 
have been that the smaller the watershed, the faster the ground water outflow and this appeared to be true in this case as well. For the three small watersheds we used a half life of 5 days for the linear reservoir and 3 days for the zero reservoir to drain completely after a storm (Table 2), which were significantly less than the calibrated parameters for WS1 with a half life of 70 days for the baseflow reservoir and 25 days for the interflow reservoir to drain. The observed (black line) and the predicted curve) are depicted in with the blue line (Fig. 2b)) and blue circles (Fig. 3c)). The Nash Sutcliffe efficiency for daily values was 0.76 and $\mathrm{R}^{2}=0.90$ (Table 3).

Using the same parameter set for rootzone storages and the subsurface flow parameters as for WS2 with the adjusted contributing areas determent before (Table 2), the hydrographs for WS3 and WS4 were predicted. By comparing the observed and predicted outflow in blue lines Figs $2 \mathrm{c}$ ) and 2d), and blue circles in Figs 3c) and 3d), it is obvious that a relatively good fit was obtained with Nash Sutcliffe efficiencies of 0.78 for WS3 and 0.90 for WS4 for daily values and $\mathrm{R}^{2}$ values near 0.80 (Table 3). The two overland flow peaks predicted in streamflow at the end August and at the end of September in Fig. 2c) were predicted by the model but not observed. The small dam at the intake structure above the weir would have stored this small overland flow volume. This structure was not observed until the weir had been built and measuring the water intake was not possible due to funding limitations. In watershed WS4 a good fit was obtained when we assumed that $70 \%$ of hillslope area was contributing to streamflow (Fig. 2d)), resulting in an efficiency of 0.90 (Table 3 ).

\section{Sensitivity analysis}

In all four watersheds, the precipitation was assumed to be evenly distributed across the watershed and that the imbalance in the water balance was caused by deeper regional flows that bypassed the weirs. However, there is a possibility that the differences in the water balances are caused by the differences in rainfall. Therefore we repeated the calibrations by assuming the whole watershed is contributing flow (both runoff and baseflow) to the weir and varied the amount of rainfall by multiplying the average rainfall by a constant. We kept all other parameters the same as shown in Table 2. The best fit in Table 3 and Fig. 2 (purple line) and Fig. 3 (purple diamonds) was obtained by taking $85 \%$ of the average rainfall for WS 2 and WS4 and $60 \%$ of the rainfall for WS3 (Table 3, third column) Overall the measures of fit in are similar for the rainfall and contributing area adjustments (Table 3 ).

\section{DISCUSSION}

The four neighboring headwater catchments (WS1, WS2, WS3, and WS4, Fig. 1) together comprise an area of 880 ha and are very similar geologically. All four watersheds are in a protected area and have never used for agriculture except for a small section of WS4. Despite that the runoff response varied greatly between WS1 and the three other smaller watersheds. The main difference in the watersheds was that WS1 has a large percentage of cloud forests and greater watershed area (635 ha), while the other watersheds located at a lower elevation had little cloud forest cover and were less than 100 ha each (Table 1). In addition, there was a rainfall gradient with approximately $17 \%$ less rainfall at the outlet of the watershed at $1350 \mathrm{~m}$ elevation than upper gage located at $1850 \mathrm{~m}$ or half way to the top of the watershed $(2270 \mathrm{~m})$.

\section{Rainfall and contributing area}

While the water balance closed for the larger (635 ha) WS1 watershed it could not be closed for the other three smaller watersheds. From other studies in cloud forest areas of Costa Rica and the island of Guadalupe, it is known that significant portions of water can bypass stream gages when the watersheds are small and located in regions with volcanic soils (Schellekens, 2006; Charlier, et al., 2008). In our study, there are two possible causes for the failure to close the water balance. First, and similar to the studies above, there is the possibility that not all the watershed area is contributing to the gage (Table 3 ) and second precipitation amounts used in the model are not representative for the areas, as there was an increase in precipitation with elevation. Note this gradient was not incorporated into the model, as we did not have sufficient rain gages.

Assuming the average measured rainfall was representative for the whole watershed, the water balance closed when in the three smallest watersheds without cloud cover (WS2, WS3 and WS4) only precipitation that fell on a fraction of the area was contributing water to the stream gage (Table 2). For instance for WS2, the contributing area for overland flow was $4 \%$ and on $80 \%$ of the area the precipitation that was not lost as evaporation became either interflow or baseflow. According to the model, the remaining $16 \%$ of the WS2 watershed area contributed to deep percolation and did not flow through the gage (Table 2). In WS3 and WS4 the contributing area for surface runoff was 4\%. In WS3 30\% contributed to subsurface flow at the gage and $66 \%$ became deep percolation. On $26 \%$ of the area in watershed WS4, the rainfall was lost as evaporation and deep percolation and did no flow through the gage. These fractions of unaccounted water (i.e., deep percolation) fall in the same range of the other cloud forest on volcanic soils in Costa Rica and on Guadalupe (Schellekens, 2006; Charlier, et al., 2008).

Assuming that the whole watershed is contributing but the rainfall varies we found that we needed to multiply the precipitation by 0.85 for watersheds WS2 and WS4 and 0.60 for WS3 (Table 3 ). In contrast, for watershed WS1 we could not get a better fit by reducing the rainfall amount. Thus, while keeping the contributing area constant we could obtain the same fit for WS2 and WS4 by decreasing the rainfall by realistic amounts of approximately $15 \%$ for those watersheds that had significant forest coverage at lower elevations (Table 3). WS3 had the water supply system intercepting water before the weir so the reduction factor of 0.60 appears to be realistic as well.

In the foregoing analysis we assumed that the precipitation was equally distributed over the watershed (by averaging the rainfall of the gage at $1350 \mathrm{~m}$ and the one at $1800 \mathrm{~m}$ ), mainly because measuring correctly precipitation in a cloud forest is extremely difficult (Frumau et al., 2011). In reality rainfall varies within a watershed and we need to examine what the rainfall pattern is and what the effect is on the discharge. Bruijnzeel et al. (2011) and Schellekens (2006) found both that the windward facing slopes and higher elevation have increased precipitation. In addition, Stadtmüller and Agudelo (1990) reported for three plots with cloud forest in the Cerro Uyuca Biological Reserve, CUBR $30 \mathrm{~km}$ south east of La Tigra National Park that the annual precipitation from June 1987 to May 1988 was $2629 \mathrm{~mm}$ at the ridge and 1372 and $1892 \mathrm{~mm}$ at lower elevations. In addition they found that in the rainy phase of the monsoon from June to September only the precipitation in July and August increased with elevation. In the dry time of the year, the cloud forest intercepted more clouds from November to March and resulted in a doubling of the amount of moisture input compared to non-cloud forest areas. 
The La Tigra National Park showed a similar trend as in the Cerro Uyuca Biological Reserve. Particularly in the periods from August through October 2008 (Fig. S5 in the Supplementary material) and from May 2009 to January 2010 (Fig. S6) the RG1 rain gage located at $1350 \mathrm{~m}$ received approximately $15 \%$ less rainfall than at RG3 at $1800 \mathrm{~m}$ (locations of the rain gages are on Fig. 1). In 2008 the rain storm on September 3 was the last event in which the $1800 \mathrm{~m}$ gage received much more rain than the lower gage (Fig. S5). In 2009, starting around July 1 the $1800 \mathrm{~m}$ gage received more rain up until the beginning of September (Fig. S6). Then starting in the middle of October in 2009 , the $1800 \mathrm{~m}$ rain gage received again more rain than the lower gage. Finally, we had also a short period in which the rainfall was measures at RG4 at the east side of the watershed at $1830 \mathrm{~m}$. Comparison with RG3 on the Westside at approximately the same elevation did not show any significant trend (Fig. S7).

In order to examine what the effect of the spatial variable rainfall was on the simulated discharge, we reran the model for the WS1 watershed with cloud forest. First we replaced the average rainfall with the rainfall at $1800 \mathrm{~m}$ and simulated the discharge (Fig. S8). To obtain a good fit, the contributing area was reduced to 0.83 with similar fit Nash Sutcliffe values of 0.86 . Changing any of other parameter values did not improve the Nash Sutcliffe values. Finally, we took the rainfall distribution from the Cerro Uyuca Biological Reserve and increased the average rainfall by a factor of two for July and August and by $250 \%$ for the dry month from November to March. This resulted in a worse fit for the predicted and observed discharge (Fig. S9 in the auxiliary material with a Nash Sutcliffe value of $0.14)$. Changing the input parameters was not effective in obtaining a reasonable fit.

Because we only have the integrated output signal from each of the watershed, it is not possible to determine from the model directly what caused the difference in amount of flow accounted at the stream gage. Therefore, we need to consider the factors individually that affects discharge. According to Goodrich, (1992) and Mamillapalli et al. (1996), channel network, drainage network density, topography, soils and climatic inputs all affect discharge. Based on the analysis in the paragraphs above, it is unlikely that precipitation pattern with elevation can be responsible for all the observed differences. IN addition, although the biological induced differences by the cloud forest in root zone (that are discussed in the next section) have an effect, it cannot be the only cause since root zone characteristics influence mostly the shape of the hydrograph in the short time and the water balance involves the long term behavior. Thus it must the geological watershed characteristics (i.e., network density and topography) are affecting the long term water balance. By studying the topographic map in Fig. S1, it can be noted that WS1 has well developed stream network that drains the concave upper parts. In the middle part of WS1 the contour lines are mostly parallel to the stream. As a consequence many springs can be found in the center of the concave hillsides. In the other three watersheds and especially WS3, contour lines were in the upper part almost perpendicular to the stream and hardly concave and relatively fewer springs could be found indicating the observed differences in the hydrology of the four watersheds can be partly explained by the drainage network and topography.

\section{Soil bio-hydrologic parameters}

The differences in soil bio-hydrologic parameters between primarily-cloud forest WS1 and the other three watersheds were surprisingly far apart since all four watersheds are located in close proximity to each other. The difference in maximum soil storage of the root zone between the cloud forest watershed (WS1) and the other three watersheds was unexpected. To ensure that we did not have false model optima, we used the same rootzone storages for WS1 as for the other three watersheds (WS2, WS3 and WS4) by changing all input parameters including evaporation and precipitation. The only other good fit was when we decreased the potential evaporation to $60 \%$ of the observed value (Table 3 ) and increased the root zone storage, $S_{\max }$ to $40 \mathrm{~mm}$ (Fig. 2a) yellow line). No other combination of parameter adjustments resulted in a reasonable model fit. This indicates that the maximum rootzone available water, $S_{\max }$, for the cloud forest and the forest at lower elevations are distinctly different.

These results are in accordance with findings in the páramo by Buytaert et al. $(2004,2006)$ who measured decreased wilting points in the agricultural catchment after two year of cultivation compared to the could forest in a paired watershed study in the Ecuadorian Highlands. Decreases in wilting point translate in a greater amount of plant-available water, and Buytaert, et al. (2005) observed even greater amount of plant-available water in laboratory measurements after the system was disturbed. In our case, as stated earlier, the $S_{\max }$ value is the maximum amount of water that can be extracted by plants in the root zone. By lowering the wilting point, more water could become available to the plant and hence provide a greater $S_{\max }$ value. Buytaert et al. $(2004,2005)$ found that the retention time for base and interflow decreased by an order of magnitude when the páramo was disturbed and subjected to drying; the wilting point also decreased significantly for the disturbed, agricultural páramo. Thus biological effects on the hydrology for the cloud forest are remarkable the same as for the páramo. Both are permanently wet which might explain why they behave differently than other systems that dry out at some time during the year.

\section{CONCLUSIONS}

The aim of the study was to compare the bio-hydrology of a cloud forest with forests at lower elevations using a simple water balance model suitable for these environments. Overall this relatively simple model fitted the observed outflow hydrographs well with relatively high Nash Sutcliffe values for daily predicted values. Despite the similar climatic and geologic characteristics of the study catchments, the model parameters, varied greatly between the cloud forest watershed and the other three watersheds in close proximity, demonstrating that biology cannot be ignored in hydrology.

The cloud forest watershed had a distinctly smaller amount of plant-available water and greater groundwater storage, resulting in watershed discharges that were four times greater than those of the other watersheds, despite only relatively minor differences in annual rainfall amount. These differences were cuase by both the geology (as it affected topography and stream network) and biological effect of the cloud forest on the water storage in the root zone. Despite limited data available to date, this modeling approach is a step forward in predicting water balances in cloud forests and forested areas in Central America, thus aiding in managing the ever growing water demand and scarce water supply resources which are threatened by both the loss of forest and pollution.

Acknowledgements. Financial support was provided by assistantships of the Departments of Biological and Environmental 
Engineering and Crops and Soil Sciences at Cornell University and The Association of American States (OAS). Research funding was made available by the Canon National Parks Science Scholars Program and Academic and Professional Programs for the Americas LASPAU.

\section{REFERENCES}

Agudelo, N., 2010. Temperature gradients in the Uyuca Mountain, Francisco Morazán, Honduras. (Unpublished data.)

Araujo, M., Costa, M.F., Aureliano, J.T., Silva, M.A., 2008. Mathematical modeling of hydrodynamics and water quality in a tropical reservoir, Northeast Brazil. Braz. J. Aquat Sci Technol., 12, 19-30.

Arnold, J.G., Srinivasan, R., Muttiah, R.S., Williams, J.R., 1998. Large area hydrologic modeling and assessment. Part I: Model Development. Journal of the American Water Resources Association (JAWRA), 34, 1, 73-89.

Barlow, M., Clarke, T., 2002. Blue Gold: The fight to stop the corporate theft of the world's fresh water. New York, The New Press, ISBN: 1-5684-816-6.

Bayabil, H.K., Tilahun, S.A., Collick, A.S., Yitaferu, B., Steenhuis, T.S., 2010. Are runoff processes ecologically or topographically driven in the (sub) humid Ethiopian highlands? The case of Maybar Watershed. Ecohydrology, 3, 457-466, 2010.

Bonell, M., Bruijnzeel, L.A., 2004. Forest, water and people in the humid tropics: past, present and future hydrological research for integrated land and water management. Cambridge University Press.

Bruijnzeel, L.A., 2004. Hydrological functions of tropical forests. Not seeing the soil for the trees? Agriculture, Ecosystems and Environment, 104, 185-228.

Bruijnzeel, L.A., 2006. Hydrological impacts of converting tropical montane cloud forest to pasture, with initial reference to northern Costa Rica. DFID Project Report.

Bruijnzeel, L.A., Scatena, F.N., 2011. Preface. Hydrometeorology of tropical montane cloud forests. Hydrol. Process., 25, 319-326.

Bruijnzeel, L.A., Mulligan, M., Scatena, F.N., 2011. Hydrometeorology of tropical montane cloud forests: emerging patterns. Hydrol. Process., 25, 465-498.

Buytaert, W., Wyseure, G., De Bievre, B., Deckers, J., 2004. The use of the linear reservoir concept to quantify the impact of changes in land use on the hydrology of catchments in the Andes. Hydrology and Earth Systems Science, 8, 108-114.

Buytaert, W., Wyseure, G., De Bievre, B., Deckers, J., 2005. The effect of land-use changes on the hydrological behavior of Histic Andosols in south Ecuador. Hydrological Processes, 19, 3985-3997.

Buytaert, W., Iñiguez, V., Celleri, R., De Bièvre, B., Wyseure, G., Deckers, J., 2006. Analysis of the water balance of small páramo catchments in south Ecuador. In: J. Krecek and M. Haigh (Eds.): Environmental Role of Wetlands in Headwaters, Springer, pp. 271-281.

Buytaert, W., Beven, K. 2011. Models as multiple working hypotheses: hydrological simulation of tropical alpine wetlands. Hydrological Processes, 25, 1784-1799.

Caballero, L.A., Rimmer, A., Easton, Z.M., Steenhuis, T.S., 2012. Rainfall runoff relationships for a cloud forest watershed in Central America: Implications for water resource engineering. Journal of the American Water Resources Association, 48, 1022-1031.

Campanella, P., Dickinson, J., DuBois, R., Dulin, P., Glick, D., Merkel, A., Pool, D., Rios, R., Skillman, D., Talbot, J.,
1982. Honduras. Country Environmental Profile. A field study. RB Associates Mclean VA. http://pdf.usaid.gov/ pdf docs/PNABC410.pdf. Last accessed May 2012.

Cavelier, J., Jaramillo, M., Solis, D., DeLeon, D., 1997. Water balance and nutrient inputs in bulk precipitation in tropical montane cloud forest in Panama. Journal of Hydrology, 193, 83-96.

Charlier, J.B. Cattan, P., Moussa, R., Voltz, M., 2008. Hydrological behavior and modeling of a volcanic tropical cultivated catchment. Hydrological Processes. Hydrol. Process., $22,4355-4370$.

Collick, A.S., Easton, Z.M., Ashagrie, T., Biruk, B., Tilahun, S., Adgo, E., Awulachew, S.B., Zeleke, G., Steenhuis, T.S., 2009. A simple semi-distributed water balance model for the Ethiopian highlands. Hydrological Processes, 23, 3718$-3727$.

Easton, Z.M., Fuka, D.R., White, E.D, Collick, A.S., Ashagre, B.B, McCartney M., S.B. Awulachew, S.B., Ahmed, A.A., Steenhuis, T.S., 2010. A multi basin SWAT model analysis of runoff and sedimentation in the Blue Nile, Ethiopia. Hydrol. Earth Syst. Sci., 14, 1827-1841.

Falkenmark, M., Chapman, T., 1993. Hidróloga comparada: Un enfoque ecológico a los recursos hídricos y de suelo. UNESCOCEDEX, Madrid.

Goodrich, D.C., 1992. An Overview of the USDA-ARS Climate Change and Hydrology Program and Analysis of Model Complexity as a Function of Basin Scale. In: Proceedings of a Workshop: Effects of Global Climate Change on Hydrology and Water Resources at Catchment Scale, Tsukuba, Japan, pp. 233-242.

Gonzales de Asis, M., O’Leary, D., Ljung, P., Butherworth, J., 2007. Improving Transparency, Integrity and Accountability in Water Supply and Sanitation. The International Bank for Reconstruction and Development/The World Bank. Washington D.C.

Harpold, A.A., Lyon, S.W., Troch, P.A., Steenhuis, T.S., 2010. The Hydrological effects of lateral preferential flow paths in a glaciated watershed in the Northeastern USA. Vadose Zone Journal, 9, 397-414.

Hastenrath, S., 2011. The intertropical convergence zone of the eastern pacific revisited. International Journal of Climatology, 22, 347-356.

Horvat O., Hlavcova, K., Kohnova, S., Danko, M., 2009. Application of the FRIER distributed model for estimating the impact of land use changes on the water balance in selected basins in Slovakia. J. Hydrol. Hydromech., 57, 4, 213-225.

IGN (Instituto Geográfico Nacional), 1956. Geología de Honduras 1: 50,000 San Juan de Flores Quad.

International Organization of Standards (ISO), 1980. Water flow measurement in open channels using weirs and venturi flumes - Part 1: Thin plate weirs. 1438/1-1980(E). Available from Global Engineering Documents at http://global.ihs.com.

Jenícek, M., 2009. Runoff changes in areas differing in landuse in the Blanice river basin - application of the deterministic model J. Hydrol. Hydromech., 57, 154-161.

Kovacs, G., 1984. Proposal to construct a coordinating matrix for comparative hydrology. Hydrological Sciences JournalJournal des Sciences Hydrologiques, 29, 435-443.

Lavaire, T, Fiallos, E., 2010. Potencial de captura de agua de los suelos de la microcuenca El Carrizal, Parque Nacional La Tigra, Francisco Morazán, Honduras. Proyecto de especial de graduación, Escuela Agrícola Panamericana, Honduras. 
Lyon, S.W., McHale, M.R., Walter, M.T., Steenhuis, T.S., 2006. The Impact of Runoff Generation Mechanisms on the Location of Critical Source Areas. Journal of the American Water Resources Association (JAWRA), 42, 793-804.

Mamillapalli, S., Srinivasan, R., Arnold, J.G., Engel, B.A., 1996. Effect of spatial variability on basin scale modeling. In: Proceedings of the Third International Conference/Workshop on Integrating GIS and Environmental Modeling. National Center for Geographic Information and Analysis, Santa Barbara, California. Available at: http://www.ncgia.ucsb.edu/conf/SANTA_FE_CD-ROM/ program.html.

Martinez, M.C., 2008. Potencial de captura de agua de los suelos de Capiro y Zapotillo, Guinope, El Paraíso, Honduras. Proyecto de especial de graduación, Escuela Agrícola Panamericana, Honduras.

Mulligan, M., Burke S.M., 2010. Global cloud forests and environmental change in a hydrological context. Final report of DFID FRP project ZF0216.

Musiake, K., 2003: Hydrology and water resources in monsoon Asia. A consideration of the necessity of establishing a standing research community of hydrology and water resources in the Asia Pacific region. Hydrological Processes, 17, 2701-2709.

Nash, J.E., Sutcliffe, J., 1970. River flow forecasting through conceptual models, Part I. A discussion of principles. Journal of Hydrology, 10, 282-290.

Pavelkova H., Dohnal, M., Vogel, T., 2012. Hillslope runoff generation - comparing different modeling approaches. J. Hydrol. Hydromech., 60, 73-86.

Peranginangin, N. Sakthivadivel, R., Scott, N.R., Kendy, E., Steenhuis, T.S., 2004. Water accounting for conjunctive groundwater/surface water management: Case of the Singkarak-Ombilin River basin, Indonesia Journal of Hydrology, 292, 1-22.

PHO (Pan-American Health Organization and World Health Organization). 2000. Evaluación de los Servicios de Agua Potable y Saneamiento 2000 en las Américas. http:// www.bvsde.paho.org/eswww/eva2000/honduras/informe/inf -00.htm. Last accessed May 2012.

Peel, M.C., McMahon, T.A., Finlayson B.L., 2004. Continental differences in the variability of annual runoff-update and reassessment. Journal of Hydrology, 295, 185-197.

San Martin, O. 2001. Water Resources in Latin America and the Caribbean: Issues and Options. Inter-American Development Bank, Environment Division. http:// www.pnuma.org/aguamiaac/SUBREGIONAL\%20MESO/M ATERIAL\%20ADICIONAL/BIBLIOGRAFIAWEBGRAFIA/Modulo\%201\%20MIAAC $\% 20 \mathrm{en} \% 20 \mathrm{el} \% 20$ contexto $\% 20 \mathrm{de} \% 20$ gestion $\% 20$ para $\% 20 \mathrm{DS} /$ Estado $\% 20 \mathrm{del} \% 20$ Rec \%20Hidrico/Doc\%204.\%20Water\%20resources.pdf. Last accesses May 2012.
Šanda, M., Císlerová, M., 2009. Transforming hydrographs in the hillslope subsurface. J. Hydrol. Hydromech., 57, 264-275 .

Sivapalan, M., 2003. Process complexity at hillslope scale, process simplicity at the watershed scale: Is there a connection? Hydrological Processes, 17, 1037-1041.

Schellekens, J., 2006. CQ-FLOW: A distributed hydrological model for the prediction of land-cover change, with special reference to the Rio Chiquito catchment, Northwest Costa Rica. The Fiesta Project, Vrije Universiteit, Amsterdam, 2006. http://www.falw.vu/ fiesta/reports/R7991 FTR Annex3_CQflow-manual-results.pdf. Last accessed May 2012.

Shumova, N., 2009. Crop water supply and its relation to yield of spring wheat in the south of Russian plain. J. Hydrol. Hydromech., 57, 2009, 1, 26-39.

Stadtmüller, T., 1987. Cloud Forests in the Humid Tropics: A Bibliographic Review. United Nations University (UNU): http://archive.unu.edu/unupress/unupbooks/80670e/ 80670E00.htm80670e/80670E00.htm. Last accessed May 2012.

Stadtmüller, Agudelo, N., 1990. Amount and variability of cloud moisture input in a tropical cloud forest. International Association of Hydrological Sciences Publication, 193, 25-32 .

Steenhuis, T.S., van der Molen, W.H., 1986. The ThornthwaiteMather procedure as a simple engineering method to predict recharge. Journal of Hydrology, 84, 221-229.

Steenhuis, T.S., Collick A.S., Easton Z.M., Leggesse, E.S., Bayabil, H.K., White, E.D., Awulachew, S.B., Adgo, E., Ahmed, A.A., 2009. Predicting discharge and erosion for the Abay (Blue Nile) with a simple model. Hydrological Processes, 23, 3728-3737.

Tesemma, Z.K., Mohamed, Y.A., Steenhuis, T.S., 2010. Trends in rainfall and runoff in the Blue Nile Basin: 1964-2003. Hydrological Processes, 25, 3747-3758.

Thornthwaite, C.W., 1948. An approach toward a rational classification of climate. Geogr. Rev., 38, 55-94.

Thornthwaite, C.W., Mather, J.R. 1955. The water balance, Publ. Climatol. Lab. Climatol. Dresel Inst. Technol., 8, 1$-104$.

UNDP: Adaptation Fund Board Secretariat., 2010. Addressing Climate Change Risks on Water Resources in Honduras: Increased Systemic Resilience and Reduced Vulnerability of the Urban Poor. UNDP PIMS 4399; Atlas IDs-Proposal 00060323, Project 00075904, HND10).

Walter, M.T., Steenhuis, T.S., Mehta, V.K., Thongs, D., Zion, M., Schneiderman, E., 2002. Refined conceptualization of TOPMODEL for shallow subsurface flows. Hydrological Processes, 16, 2041-2046.

Received 30 September 2012 Accepted 11 December 2012

Note: Supplementary Figures (S1-S9), as well as colour version of Figures 1-3 can be found in the web version of this article. 


\section{SUPPLEMENTARY MATERIAL}

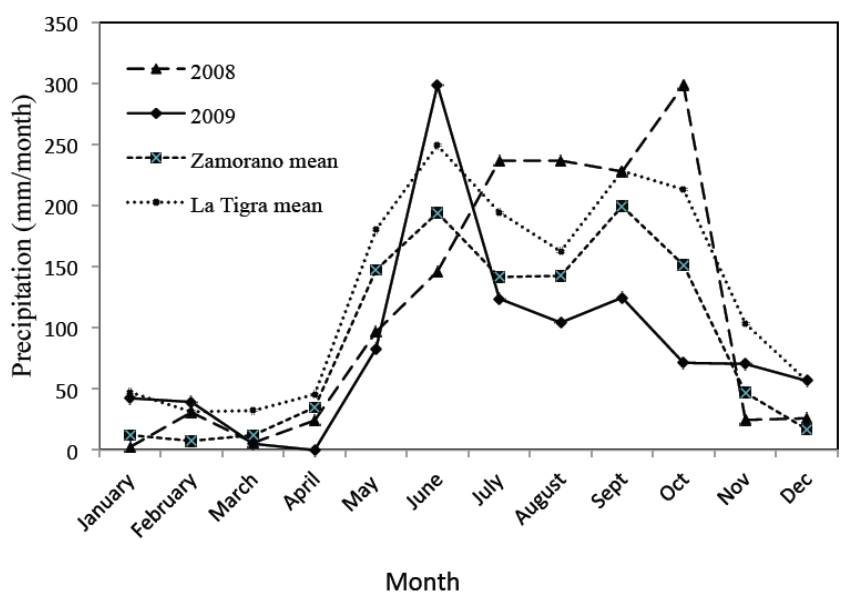

Fig. S1. Monthly precipitation at experimental site compared to long-term average Zamorano weather station and La Tigra SANAA. Source: Zamorano University (1942-2009) and SANAA (1963-2008)

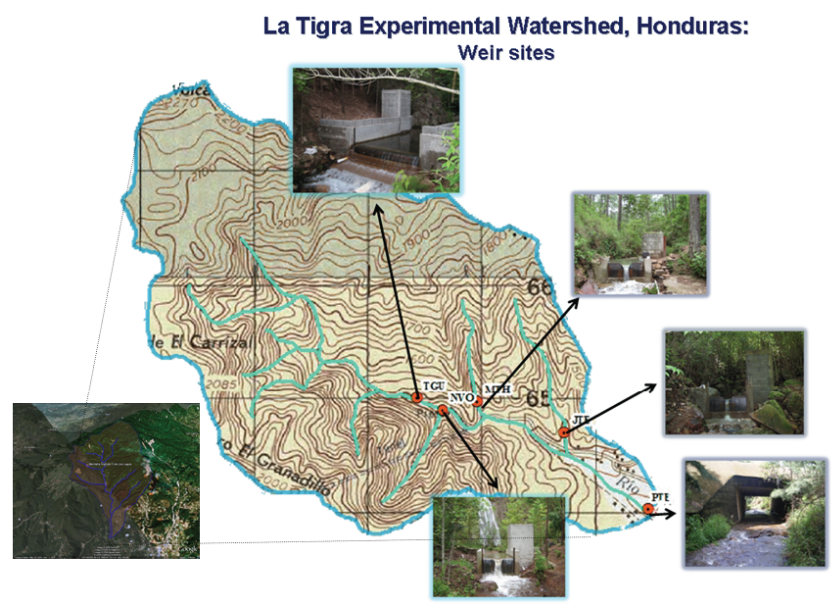

Fig. S2a. The weirs in the watershed.

La Tigra Experimental Watershed, Honduras, C.A.

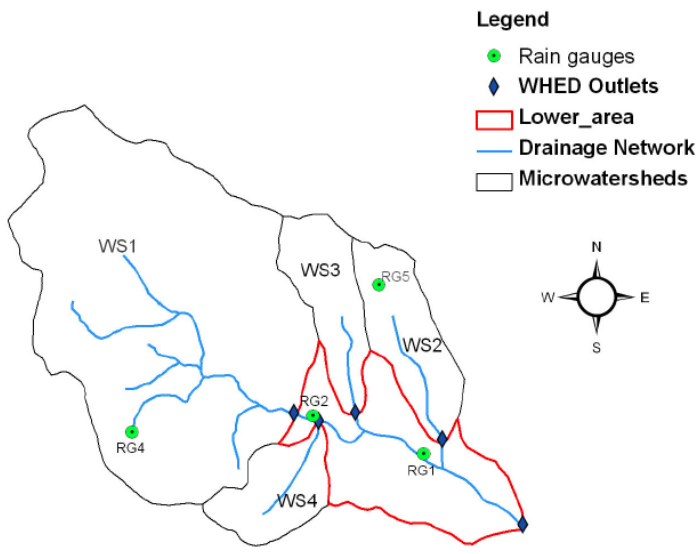

RG3

$0375750 \quad 1,500$ Meters

$1,1,1,1,500$

Projected Coord. System
Datun: NAD_1927
UTM_Zone_16N

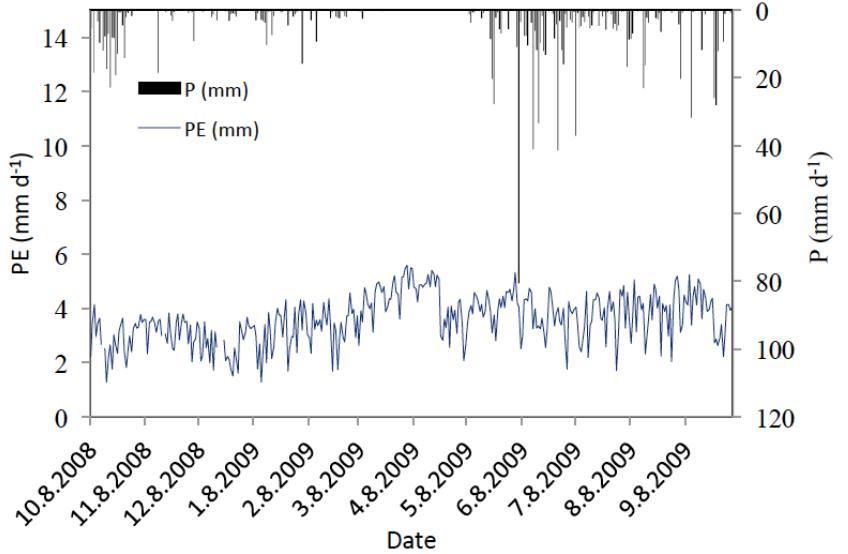

Fig. S3. Daily average precipitation $(\mathrm{P})$ and potential evaporation (PE) used in SWB model for the La Tigra National Park.

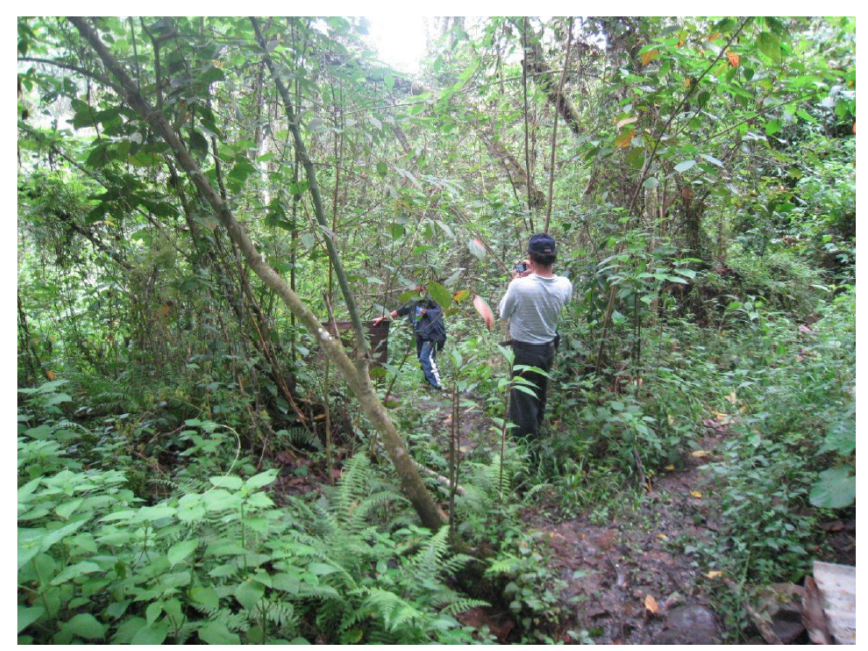

Fig. S4. Saturated area in the La Tigra National park. Spring house in the back collects the spring water.

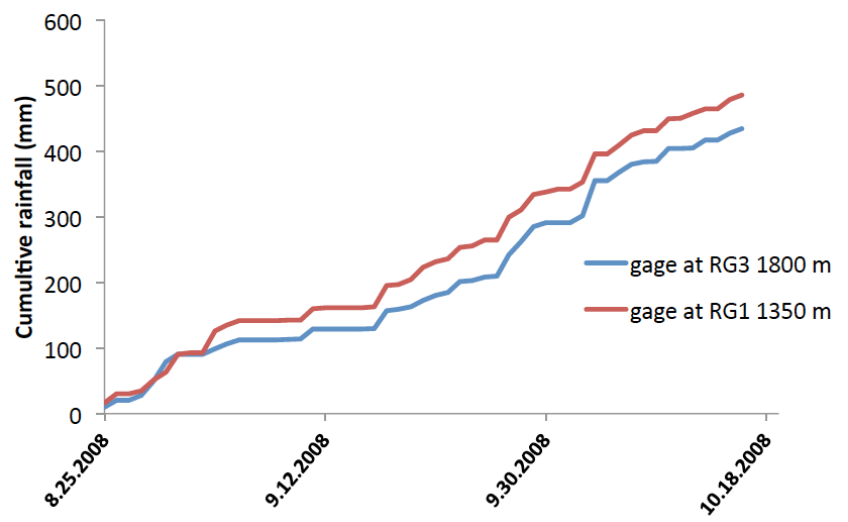

Fig. S5. Comparison of the rainfall of the rain gages RG1 at 1350 $\mathrm{m}$ and RG3 at $1800 \mathrm{~m}$ elevation for the period starting at August 25 through October 16, 2008 in the La Tigra National Park in Honduras.

Fig. S2b. Location of instrumentation in the watershed. 


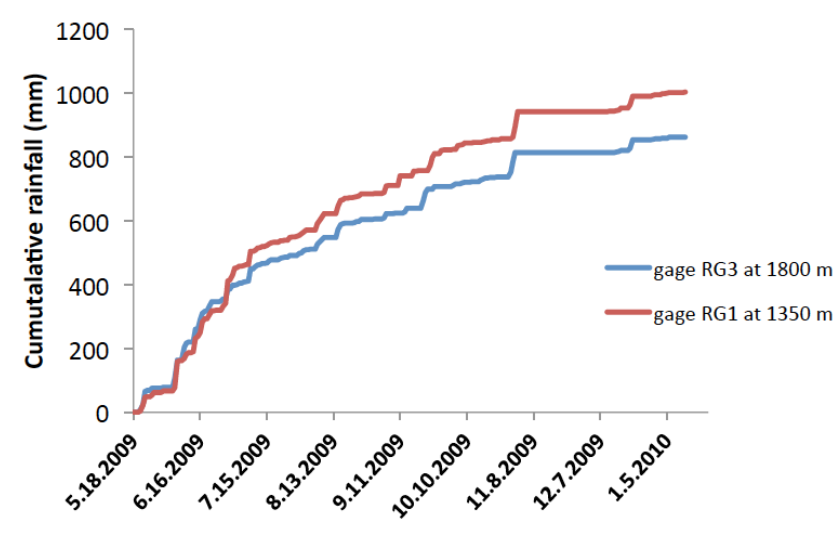

Fig. S6. Comparison of the rainfall of the rain gages RG1 at 1350 $\mathrm{m}$ and RG3 at $1800 \mathrm{~m}$ elevation for the period starting at May 18, 2009 through January 10, 2010 in the La Tigra National Park in Honduras.

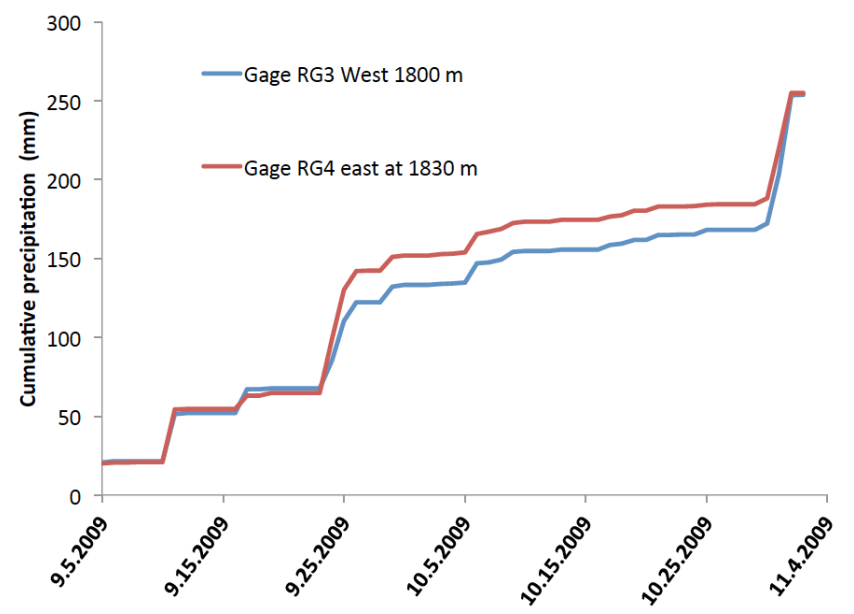

Fig. S7. Comparison of the rainfall of the rain gages RG3 at 1800 $\mathrm{m}$ at the east site and RG4 at the west site at $1830 \mathrm{~m}$ elevation for the period starting at September 5, 2009 through October 4, 2009 in the La Tigra National Park in Honduras.

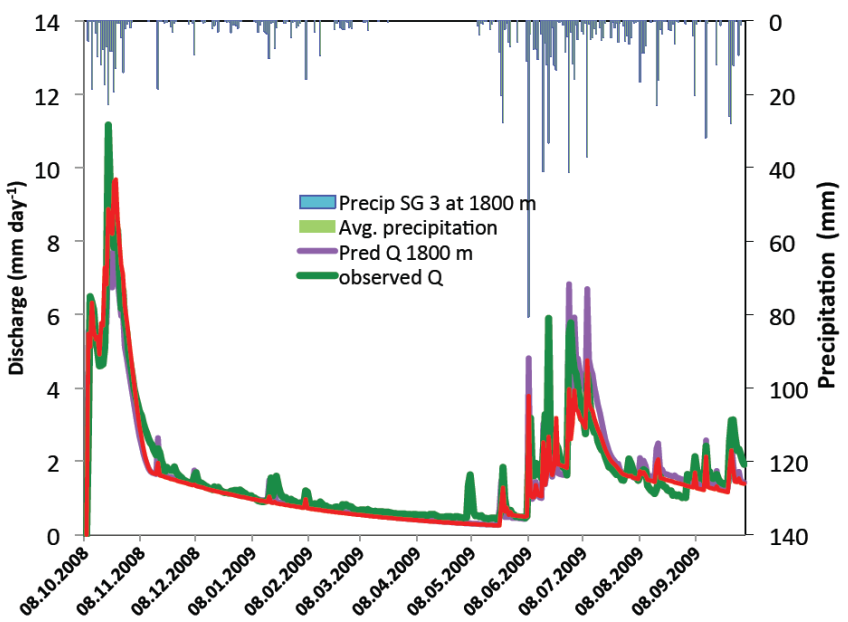

Fig. S8. Comparison of observed and predicted daily total stream discharges for the watershed WS1 and the average rainfall and parameters listed in Table 2 and the with rainfall at gage RG3 at $1800 \mathrm{~m}$ and parameters listed in Table 2 with the exception of the contributing hillslope area that was reduced to 0.83 .

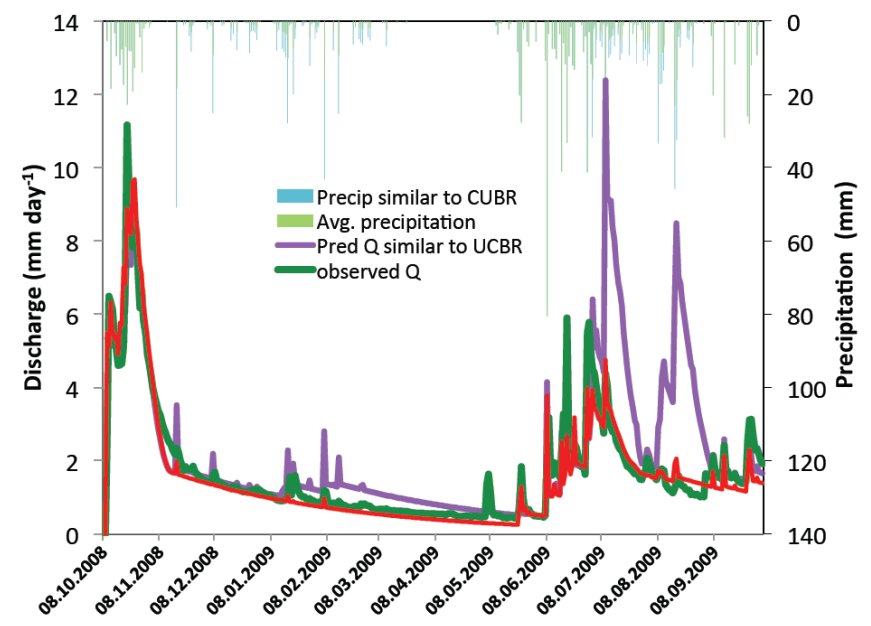

Fig. S9. Comparison of observed and predicted daily total stream discharges for the watershed WS1 and the average rainfall and parameters listed in Table 2 and with rainfall that had the same characteristics at the rainfall for the watersheds that were listed in Table 2 with the exception of the contributing hillslope area that was reduced to 0.83 and the rainfall for the rain. 